\title{
IMPLEMENTING MULTIPASS STRATEGY TO IMPROVE STUDENTS' SKILL IN READING COMPREHENSION
}

\author{
Hasrat Sozanolo Harefa \\ Institut Keguruan dan Ilmu Pendidikan (IKIP) Gunungsitoli \\ sozanoloe@gmail.com
}

\begin{abstract}
Abstrak
Penelitian ini bertujuan untuk meningkatkan keterampilan mahasiswa dalam memahami bacaan dengan menggunakan Strategi Multipass di semester III Program Pendidikan Bahasa Inggris IKIP Gunungsitoli 2015/2016. Penelitian ini Penelitian Tindakan Kelas. Subyek penelitian adalah mahasiswa semester III kelas A Program Studi Bahasa Inggris sebanyak 22 orang. Data penelitian ini terdiri dari data kuantitatif dan kualitatif. Data kuantitatif diperoleh melalui nilai tugas dan nilai tes membaca. Dan data kualitatif melalui hasil pengamatan. Hasil pelitian dari siklus 1 -siklus 3 menunjukkan bahwa Strategi Multipass mampu meningkatkan keterampilan mahasiswa dalam memahami bacaan.
\end{abstract}

Katakunci: memahami bacaan, strategi multipass

\begin{abstract}
This research was aimed at improving students' skill in reading comprehension by using Multipass Strategy in the third semester of English Department of IKIP Gunungsitoli in 2015/2016. It was conducted by using Classroom Action Research. The subjects of the research were the students of class A of the third semester of English Department. The class consisted of 22 students. Then, the data of this research were quantitative and qualitative data. The quantitative data was gained from the score of the students reading task and test in every cycle. The qualitative data was collected through the result of observation. The finding of the research from cycle 1 up to cycle 3 showed that Multipass Strategy enabled to improve the students' skill in reading comprehensi on as shown by the result of students' test in reading comprehension.
\end{abstract}

Keywords: reading comprehension, multipass strategy

\section{INTRODUCTION}

\subsection{Background of the problem}

Reading comprehension is the process of extracting and constructing meaning through interaction and involvement with written language. It involves three main goals - meaning, learning, and pleasure (Haris \& Steve: 2007). According to Westwood (2008), reading comprehension is a process of active thinking where a reader constructs meaning to find a deeper understanding of concepts and information obtained in a text. During reading, students represent their experience with reading, and they use this experience to construct meaning. From a reader perspective, understanding what is read is related to the individual's experience and interpretations of these experiences.

In many schools, reading comprehension becomes a problem in English teaching. The main problem that is faced by schools is the low of students' skill in reading comprehension. Based on the researcher's teaching experience and observation at IKIP Gunungsitoli, especially the third-semester students of English Department in academic year 2015/2016, most students' achievement in reading skill subject was lower than the standard minimum criteria of reading achievement (70). For 22 students, there were only 7 students who achieved the criteria or $31,8 \%$ of the students. Briefly, 
there was more than 70 percent of students did not reach the standard score of reading achievement.

Basically, there are many possible reasons why the students may experience difficulty in learning to read, such as uninteresting reading material, irrelevant media, and teaching strategy. Among the factors, teaching strategy is the most crucial reason that influences the students' low achievement in reading comprehension. There is a tendency that the lecturer tends to teach reading in a conventional way, for examples reading aloud, silent reading, asking and answering the question, discussing, teacher center learning, etc. Conventional teaching fundamentally concerns with classical models and is monotonous. On the other hand, the students expect the various teaching or learning models in reading comprehension class in order they feel more enthusiastic and convenient to do their learning activities.

One reading strategy that has not been used largely in reading comprehension, namely Multipass Strategy. Multipass Strategy is a strategy used to improve student reading comprehension. It helps students who have problems in identifying the main idea, supporting idea, and detail information, or processing and recalling information after reading. This reading strategy contains three steps (surveying the reading, sizing up the information, and sorting out the text) through a reading text to identify text structure and become familiar with main ideas and organization, read questions at the back of passage and guess an answer. The student then read the text to find the correct answers to the questions (Schumaker et al.,: 1982).

\subsection{Formulation of the Problem}

To what extent can Multipass Strategy improve students' skill in reading comprehension at the third semester of English Department of IKIP Gunungsitoli?

\section{METHOD}

This research was conducted by using classroom action research that consisted of three cycles with four stages in every cycle (plan, action, observation, and reflection). One cycle was divided into four meetings. Three meeting were used for treatments and another meeting was used for a test. Totally, there were twelve meetings during the research in which it carried out twice a week and took 100 minutes each meeting ( 2 credits $\mathrm{x} 50$ minutes). The subjects of this research were 22 students of class A of the third semester of English Department of IKIP Gunungsitoli (3 males and 19 females). Another participant was an English lecturer who was teaching reading skill subject at the same level of students as the collaborator. Furthermore, the data was collected by using some instruments according to the kinds of data. Quantitative data was gained through reading comprehension task and test. Reading comprehension task was given in each meeting, while reading comprehension test was given in each cycle. Then, qualitative data was gained through observation result and field note. The observation was done during the class, while the interview was done after the class.

\section{FINDING AND DISCUSSION}

This research had two different kinds of data analysis, namely quantitative and qualitative data. The quantitative data was gained through tasks and tests. And the qualitative data was gained through observations, field notes, and interviews. The quantitative data was aimed to answer the research question about to what extent Multipass Strategy improve students' skill in reading comprehension at the third semester of English Department IKIP Gunungsitoli. Meanwhile, the qualitative data was aimed to answer the research question about what factor influence the changes of student's skill in reading 
comprehension in the third semester of English Department IKIP Gunungsitoli through Multipass Strategy.

This research started on November $4^{\text {th }}, 2015$ - December 11 ${ }^{\text {th }}, 2015$. It consisted of three cycles. Each cycle was divided into four meetings. Three meeting were used for treatments and another meeting was used for the test. Totally, there were twelve meetings during the research in which it carried out twice a week and took 100 minutes each meeting ( 2 credits x 50 minutes).

The result of students' task in reading comprehension from cycle 1 up to cycle 3 is shown in the following figure.

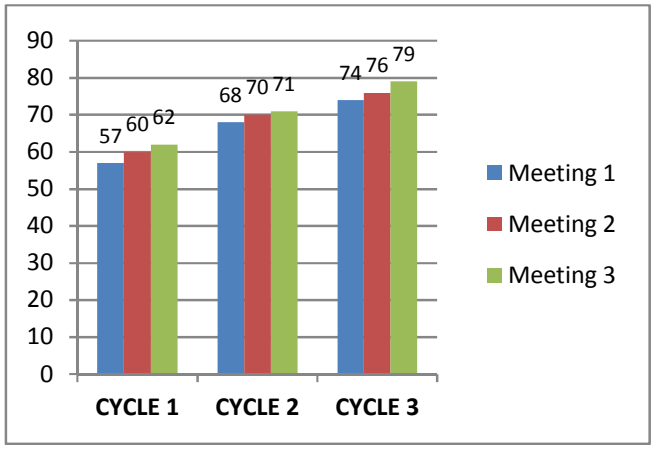

Figure 1. The average of students' task achievement in reading comprehension by using Multipass Strategy

The improvement of the students' reading comprehension achievement in the research was supported by the result of observation. Based on the observation done by the collaborator, the implementation of teaching matched with the lesson plan. This fact was also supported by the collaborator's notes through the lecturer's observation sheet and the students' observation sheet. The observation sheets showed that both the researcher and the students had done the teaching activities as written in observation guidelines.

Furthermore, the collaborator also gave the description of the teaching process through field notes. She took some notes about the lecturer's activities and the students' activities since the beginning of conducting learning process until the end. In opening the class, the researcher greeted and checked the students' attendance. The students responded to the lecturer well. After that, the researcher introduced Multipass Strategy to the students. He explained the lesson by using LCD projector and other relevant media. The students listened to the lecturer's explanation. They sometimes took notes and gave questions related to the lecturer's explanation. Then, the students paid attention to the researcher when the researcher demonstrated a Multipass Strategy. After the researcher felt that the students had understood the use of the strategy, he asked the students to do a task. The task was necessary for the students to comprehend a text by using Multipass Strategy. And the students used the strategy in reading comprehension seriously. Finally, the researcher sometimes approached the students to guide them to use Multipass Strategy.

Besides the result of reading task, the quantitative data was also gained through the result of the reading test that was conducted in every cycle. The result of the reading test is shown in this following figure.

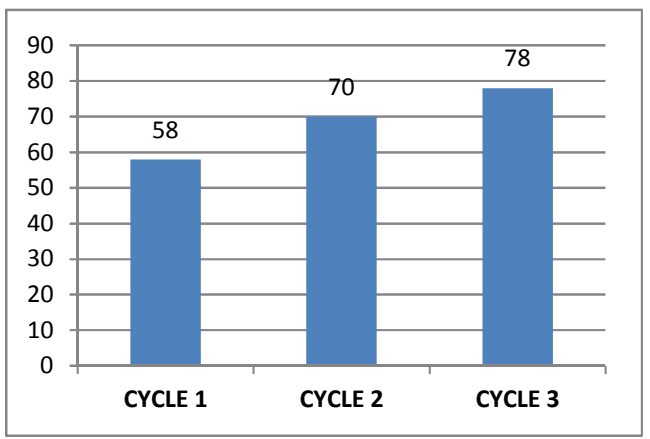

Figure 2. The average of students' test achievement in reading comprehension by using Multipass Strategy

This figure described that there was an improvement of students' test achievement in reading comprehension by 
using Multipass Strategy in every cycle. In cycle 1, the students' score was 58. In cycle 2, the students' score increased to 70. And In cycle 3, the students' score increased highly to 78 . In short, the students' test achievement proved that Multipass Strategy was very effective to be used in improving the students' skill in reading comprehension.

Furthermore, by looking at the number of students who reached the standard minimum criteria for reading achievement in cycle 3, most of the students reached the target of success. From 22 students who followed the test, there were 18 students who got $\geq 70$. The number of 18 students was equal to $81,8 \%$ of the total students. In conclusion, the test result showed that Multipass Strategy improved the students' skill in reading comprehension and the percentage of students who reached the standard minimum criteria was higher than $75 \%$ (the indicator of success) Therefore, the researcher and the collaborator decided to end this classroom action research.

By comparing the percentage of the students who reached the standard minimum criteria for reading comprehension achievement in each cycle, it seemed clear the improvement of students' skill in reading comprehension by using Multipass Strategy. In cycle 1, there was $40,9 \%$ of 22 students who reached the criteria of reading achievement. This result was equal to 9 students. Furthermore, the result of cycle 2 increased significantly $22,7 \%$ as compared to the previous cycle. The result of cycle 2 was equal to 14 students. And in cycle 3, there was $81,8 \%$ of total students who reached the standard minimum criteria for reading achievement, or equal to 18 students. Finally, the researcher concluded that the students had improvement in reading comprehension by using Multipass Strategy.
This classroom action research focused on improving students' skill in reading comprehension by using Multipass Strategy. The researcher proposed two purposes of the research to find out the extent Multipass Strategy improve students' skill in reading comprehension and to find out the factors that influence the changes of students' skill in reading comprehension. Before conducting the research, the researcher had conducted observation through the teaching-learning process. Based on the observation, there were more than $70 \%$ of students who did not achieve the standard minimum criteria for reading achievement (70). The data mentioned that there were 15 students who were failed among 22 students. Similarly, there was $31,8 \%$ of total students who reached the standard minimum criteria.

Furthermore, the researcher conducted action research to solve the students' problem in reading comprehension. The research was conducted in three cycles, which contained four meeting in each cycle. The researcher treated the students by using Multipass Strategy in reading comprehension Multipass Strategy was a relevant strategy that was used to solve student's difficulty in reading comprehension as suggested by Masullo and Settlow (2007). This strategy divided into three systematic steps; survey, sizeup, and sort-out pass. In fact, Multipass Strategy enables the students to comprehend the text well after applying continuously.

\section{CONCLUSION}

From the above description, it can be concluded that Multipass Strategy improves students' skill in reading comprehension. The result of the quantitative data shows that students have made an improvement in reading comprehension in every cycle by using Multipass Strategy and reach the indicator of success. 


\section{REFERENCES}

G, H. K. (2007). Reading Comprehension to Students With Learning Difficulties. New York: The Guilford Press.

Harris, K. a. (2007). Reading Comprehension to Students With Learning Difficults. New York: The Guilford.

King, C. a. (2004). Teaching Reading Skill in a Foreign Language. Oxford: Oxford University Press.

Klingner, J. K. (2007). Teaching Reading Comprehension to Students with Learning Difficulties. New York: The Guilford Press.

McNamara, D. S. (2007). Reading Comprehension Strategies : Theories Interventions and Technologies. New York: Lawrence Erlbaum Associates, Inc.

Nunan, D. (2003). Practical English Language Teaching. New York: McGraw-Hill Companies, INC.

O'Connor Rollanda E, a. V. (2011). Handbook of Reading Interventions. New York: The Guilford Press.

Schumaker, J., Deshler, D., Alley, G., Warner, M., \& Denton, P. 1982. Multipass: A learning strategy for improving reading comprehension. Learning Disability Quarterly, 5, 295-304.

Schumam. (2006). Reading Assessment and Instruction for All Learners. New York: The Guilford Press.

Westwood, P. (2008). What Teachers need to Know about Reading and Writing Difficulties. Australia: ACER Press. 